\title{
THE OUTSTANDING TURKOLOGIST AND SCIENTIST ADKHAM TENISHEV AND HIS CONTRIBUTION TO THE STUDY OF THE HISTORY OF THE TURKIC AND TATAR LITERARY LANGUAGES
}

\author{
Fanuza Shakurovna Nurieva, \\ Kazan Federal University, \\ 18 Kremlyovskaya Str., Kazan, 420008, Russian Federation, \\ fanuzanurieva@yandex.ru.
}

\begin{abstract}
The article studies the achievements of Adkham Tenishev (born 24.04.1921, died 1.07.2004), a world-renowned scientist and one of the most prominent figures in Turkic linguistics, in the field of the history of the Turkic and Tatar literary languages. The scientist's works and linguistic philosophy are analyzed through his contribution to the modern linguistic theory and the development of Tatar linguistics. The article presents a general overview of A. Tenishev's research, related to ancient Turkic written monuments, modern languages of the peoples of Central Asia, historical-comparative grammar, and the history of Turkic languages. Of great importance is the contribution made by the six-volume collective work, a comparative study of the history of the Turkic languages, which is significant for the research into the rich heritage of the Turkic peoples, for it describes the historical development and the changes that occurred in different Turkic languages. Based on the achievements of world science, the article presents A. Tenishev's general theoretical views on the history of the Turkic literary language and thoroughly analyzes the features and conditions that influenced the formation of the literary language. It was found that the works of the scholar opened up great scientific and methodological opportunities for writing the history of the modern Tatar literary language, which makes it possible to find answers to many questions.
\end{abstract}

Key words: Adkham Tenishev, Turkology, Tatar language, Turkic languages, history of the literary language.

\section{Introduction}

The science of the history of language is closely related to the history and culture of the people. A new field of science called the history of the literary language was formed as a branch of linguistic history in philology in the 1960s and 1970s. The theoretical founder of the literary language history in Turkic linguistics was A. Tenishev. Adham Tenishev was a world-renowned Turkologist, who headed the Department of Turkic and Mongolian Languages at the Institute of Linguistics of the Russian Academy of Sciences in Moscow, the centre for Altaistic research for 40 years.

The significance of our work refers to the basic scientific principles and the unique nature and functions of the literary language that determine the literary language historical aspects in A. Tenishev's works, distinguishing them from historical grammar and other similar areas of research. Indeed, the histories of nations are rooted not only in their economic development and political events but also in the rich and valuable cultural heritage, created over the centuries. The purpose of our work is to highlight the features, identified by A.
Tenishev in his research, based on the literary monuments, forming the essence of the Turkic literary language: processed, normalized, and functional-stylistic variability, continuity, and traditions. Although the scientist's wide-ranging activities were mentioned in the works of V. I. Kirsanov [Kirsanov, 1980, pp. 3-25], A. V. Dybo [Dybo, 2001, pp. 6-18], D. M. Nasilov [Nasilov, 2006, pp. 6-12], I. B. Bashirova [Bəshirova, 1999, pp. 3738], F. Sh. Nurieva [Nurieva, 2001, pp. 18-22; 2004, pp. 19-45], A. Tenishev's achievements in the field of the history of the Turkic literary language have not been given proper evaluation. For the first time, our work evaluates Adkham Tenishev's achievements in the study of the history of the Tatar literary language, its evolution, and variability. A. Tenishev's works suggest that the history of any literary language should be examined based on the scientific approach, and argue that not a single Turkic language was studied according to this principle. Today, almost all works, written in the old Tatar language, have been examined by scientists and included in the scientific circulation. Over the past two decades, monographs have been published by I. B. Bashirova [Bəshirova, 
1999], F. Sh. Nurieva [Nurieva, 2004], a collective work [Tatar ədəbi tel tarikhy, 2015, 2017], and other scientists who studied the history of the Tatar literary language, based on the theoretical tenets and scientific methods of A. Tenishev. These works determine the preservation level of the written linguistic tradition and its norm, examine the development and changes of the old Tatar literary language and the local variants of the modern literary language.

We used the following methods of analysis in this work: the method of general linguistic description and exploration was used to discover facts from the scientific activities of the scholar; the historical-comparative method was used to compare the literary norms and the variants of the literary language associated with the contemporary era.

\section{Main Part. A brief overview of the life and sci- entific activity of the scholar.}

The turbulent, broad-minded scientist Tenishev owed his origin to the family of prince Tenishev, who lived in the $15^{\text {th }}-16^{\text {th }}$ centuries. Many of his numerous grandchildren eventually converted to Christianity; however, the descendants of Ishmuhamet and Shukur-Ali remained Muslims. Adkham Tenishev, born on April 24, 1921, in Penza, belonged to the branch of Shukur-Ali. Over many years, Tatar princes received awards from the government for bravery in military service and achievements in science. For example, Tsar Vasily Ivanovich gave Tenish Kugushev significant plots of land. Subsequently, these lands were passed to his sons Eniki Yamash and Isash. The famous Tatar writer Amirkhan Eniki came from this family too. In the new era, the Ishmuhamet and Eniki families have raised a significant number of outstanding talents. For example, Kolynchyk Enikiev was the grandfather of the famous Russian writer A. I. Kuprin. Fourteen generations of the Ishmukhametov family are known to have lived in the Penza Region. This lineage is famous for raising the world-famous theologian Musa Bigiev, the writer Zahir Bigiev, and the first Tatar revolutionary and writer Gafur Kolakhmetov [Tenishev, 1996, pp. 397-401; Nurieva, Kurbatov, 2003, pp. 46-47].

The future scientist, who promoted the development of Tatar culture, was brought up in the family that highly appreciated knowledge. He read Arabic, Persian, Russian books, and ancient manuscripts, written in Arabic graphics, stored in his personal library. Adkham Tenishev's father Rahim Mubinovich and his mother Amina Alimovna were altruistic people who made a great contribution to the development of Tatar culture. His father studied at the Kazan Real School and maintained relationship with such famous Tatar personalities as G. Tukay, he also took part in Tatar performances along with G. Kamal, F. Amirkhan, and G. Kulakhmetov. Rizaetdin Fakhretdinov, a wellknown theologian, dedicated a special chapter to the scientist's grandmother Habibjamal in his book "Мәшһүр хатыннар" ("Prominent Women") [Nurieva, 2001, p. 19].

Many of the qualities that Adkham Tenishev possessed were formed under the influence of his family, where he grew up seeing his parents and relatives, descended from the Morzas, as highly educated people devoted to their nation. We do not know exactly when he first had the idea of studying Turkic languages, but after leaving school and choosing a technical career, Adkham Tenishev entered the Faculty of Oriental Languages of Leningrad University in 1941, from which he graduated in 1945 with a degree in Turkology. The worldrenowned scientists N. Dmitriev, A. Kononov, Y. Bertels, I. Krachkovsky were his teachers. It should be noted that our compatriot and the great scientist S. E. Malov played a major role in the scientific work of Adkham Tenishev. Tenishev presented his Ph.D. thesis on the ancient heritage of the Uyghur written literary language "Алтун Ярук" (Altun Yaruk) under the supervision of S. E. Malov in 1953. In 1954, the young scientist was appointed to work at the Institute of Linguistics of the USSR Academy of Sciences in Moscow. Shortly after (in 1956), at the request of the Chinese Academy of Sciences, he was sent to China for three years to teach linguists, specializing in the Turkic languages. His large-scale scientific activity was very intense during this period. He taught Turkish and took pains with training postgraduate students to be experts in the Turkic languages. Subsequently, his disciples became great scientists. While working abroad, he embarked on scientific trips to study the spoken language in the areas inhabited by the Turkic peoples of the Tibet, taking detailed notes and keeping diaries. Upon his return to Moscow, in 1959, as a result of his work in China, he published numerous articles and two books, in which he analyzed the expedition materials, collected in the regions of Xinjiang, Qinghai, and Gansu. Adkham Tenishev was the first scientist to study the history of the Salar Turks. In 1969, he successfully presented his doctoral dissertation "Строй саларского языка" ("The Structure of the Salar Language") based on the materials on the 
Salar language. The work proves that the Salar language, which was considered to be one of the dialects of the Uyghur and Turkmen languages, is an independent language, which is confirmed by broad historical, ethnogenetic, and comparative linguistic materials. This work was published as a separate book in 1976. In 1976, the monograph "Строй сарыг-югурского языка" ("The Structure of the Saryg-Yugur Language") was published; the language, phonetics, and vocabulary of the Yellow Uyghurs in the first section, and the Shira Uyghurs in the second section are analyzed with the accuracy inherent in A. Tenishev's work [Tenishev, 1976, (Stroi...)]. For future generations of researchers, the novelty and depth of Adkham Tenishev's scientific research are as significant as the certainty of the principles and criteria set for distinguishing a dialect. Forty years later, his diary, rich in ethnographic materials, which he collected during his work in China, was published [Tenishev, 1995].

After being appointed head of the Department of Turkic Languages at the Institute of Linguistics of the Russian Academy of Sciences in 1963, Adkham Tenishev went on to study urgent scientific issues and write collective works with his colleagues. Fundamental works on the historicalcomparative study of the Altaic languages and Turkic languages, in particular, were published under his scientific and administrative supervision and received world-scale significance. The breadth and versatility of the tasks set by the scientist and the scientific depth and novelty of the issues, raised in his works, brought Adkham Tenishev fame as an outstanding scientist in Turkology. Adkham Tenishev, a person with a broad scientific outlook, who shared his knowledge with others, led the department for 40 years, creating a favourable scientific environment. Preparation and publication of the etymological dictionary of the Turkic languages in the Department of Turkic and Mongolian Languages, preparation and publication of the encyclopedic volume "Төрки телләр" (“Turkic Languages") within the framework of the program "Дөнья телләре" [Iazyki mira, 1997] were headed by the scholar (he was their editor-in-chief and the author of many articles) A. Tenishev is described as an experienced leader, a worthy successor of the scientific heritage of his mentor N. K. Dmitriev [Dybo, 2001, pp. 6-18]. Based on the achievements of Turkology, the program of the six-volume "Төрки телләрнең тарихи-чагыштырма грамматикасы" ("Historical and Comparative Grammar of the Turkic languages") was compiled, aimed to reconstruct the ancient Turkic language phenomena; the scientists of the department conducted fruitful work to prepare individual volumes for publication. The first four volumes of the work "Фонетика" (Phonetics) [Sravnitelno-istoricheskaia grammatika, 1984], "Морфология" (Morphology) [Sravnitelno-istoricheskaia grammatika, 1989], "Лексика" (Lexis) [Sravnitelno-istoricheskaia grammatika, 1997; 2001] were published with the direct participation of the scientist. Adkham Tenishev not only organized the authors' activities but also wrote individual chapters. These volumes reconstruct the ancient Turkic basis of the language using the historical-comparative method. According to the famous scientist F. Khisamova, "The publication of these major works, corresponding to the world standards in modern linguistic research, allows us not only to study the history of the Turkic languages in general but also to explain in a new way some issues of the grammatical structure of certain Turkic languages. In traditional Turkology, for example, languages that belong to the Kipchak group, including the Tatar language, were considered to be "new" languages that historically have undergone many structural changes. The results of the reconstruction of the ancient and most ancient Turkic language on a new scientific basis allow us to assert in many cases the significant proximity of the Tatar language to ancient Turkic" [Khisamova, 2013, p. 33]. Upon the publication of three volumes on Grammar, Adkham Tenishev was awarded the Al-Bukhari Waqf Award by the Muslim Committee of Asia. The significance of these works was recognized by the entire Eastern world.

The fifth volume of "Grammar" titled "Региональные реконструкции" (Regional Reconstructions) [Sravnitelno-istoricheskaia grammatika, 2002] was prepared under the guidance and with the participation of A. Tenishev. The research was conducted with the aim to restore modern Turkic languages and dialects and analyze written monuments based on genetic groups. The work clarifies the history of particular Turkic languages, shows their intersection or disintegration, the development or change of their dialectical systems, and reconstructs the Proto-Turkic (early) period. However, the scientist was not to see how the last sixth volume "Пратюркский язык. Картина мира пратюрков" ("Pra-Turkic Language. The Praturks' Picture of the World") [Sravnitelno-istoricheskaia grammatika, 2006] of the Historical Grammar was published and appreciated as the work that raised 
Turkology to its highest level. He passed away on July 11, 2004.

In addition to the Turkic languages, the department, headed by Tenishev Adkham, paid special attention to the historical studies of the Mongolian languages, as well as the compilation of a full dictionary of the Mongolian language.

When Adkham Tenishev was appointed executive editor of the European Linguistic Atlas under the jurisdiction of the international organization UNESCO in 1977, his articles on the prospects of studying the Turkic dialectology appeared in scientific journals. After the death of academician A. Kononov in 1987, he was appointed head of the Russian Committee of Turkologists. His duties included the responsibility for determining the direction of the Russian Turkology development, for training specialists in national republics, for writing and publishing scientific works covering the most important areas of Turkology, for convening an annual Turkological Plenum, and holding scientific conferences. The most prestigious journal in Turkology, "Советская Тюркология" ("Soviet Turkology"), was first published on April 1st, 1970. The management of this journal, which is the publishing body of the Academy of Sciences, also fell on his shoulders. When Tenishev was appointed editor of the "Евразия халыклары дастаны" ("The Epic of the Eurasian Peoples") in the Russian Cultural Foundation in 1990, the dastans of the Kyrgyz, Karachay-Balkar, Karelo-Finnish, Buryat, and many other Turkic peoples were published with his editorship, which gained this work worldwide recognition. The third and fourth volumes were prepared and published timed for the 1000th anniversary of "Manas" in 1995. Adkham Tenishev thoroughly studied the languages of the Turkic peoples living in the Crimea - the Crimean Tatars, Karaites, Krymchaks, their history, and published several significant works on this topic.

The selfless work of the scientist in several major branches of philology was highly appreciated worldwide; A. Tenishev was elected an honorary member of the Turkish Language Association and a corresponding member of the Finno-Ugrian Society in 1982. Turkish President Suleyman Demirel awarded the scientist Adkham Tenishev with the Likyat nişanı medal in 1998.

Adkham Tenishev's research into the history of the Turkic and Tatar literary languages. The scientific activity of Adkham Tenishev covers a wide range of fields. The main works can be divided into four broad areas: modern languages of
Central Asian peoples, ancient Turkic written memoirs, historical-comparative grammar, and history of Turkic languages.

In our article, we will focus on discussing one of the scientific areas of the scientist's research related to the study of Turkic written literary memoirs.

In the 1960s and 1970s, a new trend of linguistics was formed - the science of the history of the literary language, studying the structure and development of language norms and styles. The scientist Adkham Tenishev was the theoretical founder of the basic tenets substantiating this trend in Turkology. To create an accurate picture of the history of the language development and describe the correct allocation of its general and particular features, the works of A. Tenishev present the study of the history of the Turkic languages in three areas: 1) historical grammar of the national language; 2) historical grammar of the literary language; 3 ) history of the literary language. These areas significantly differ from each other in terms of their purpose, methods of study and the data that served as the basis for the study. Each area depicts the interrelationships of language units and the main principles of study [Tenishev, 1988, pp. 67-78].

The study of the national language history is conducted based on its structure in historical grammar, the history of literary language studies, the history of its formation in the general Turkic language group, or in a particular language, the division of the literary language into periods, and the features of its use in various written monuments of antiquity. In the history of the literary language, the development and change of language norms and styles are analyzed based on the historical and social situation; that is, in their functional aspect. Concerning the history of the literary language, it is important not only to determine, to which group the linguistic elements of the Turkic language belong but also to identify the functions of their lexical, morphological, and syntactic components, the use of different poetic devices and their poetic functions in written works. Despite the difference in goals and trends, the history of the literary language and historical grammar are closely interrelated when it comes to the history and culture of the people. Thus, when studying the history of the Turkic languages, Adkham Tenishev pays special attention to the fact that the nature and functions of the spoken and written literary languages are not the same, and the history of the written literary language must be studied separately, as well as the structure of the spoken language. The literary lan- 
guage, reflected in ancient written monuments, as a rule, does not coincide with the spoken language, since the language of monuments preserves ancient written traditions and historical continuity. In all the works of the scholar, the emphasis is placed on the fact that when studying the language and the general linguistic structure of written works, the history of both branches should be analyzed separately [Tenishev, 1976 (O postroenii...), pp. 230 232; 1988, pp. 67-78].

According to Adkham Tenishev, despite the work done by the turkologists V. V. Radlov and S. Y. Malov, who first studied the Turkic literary language, in which the importance of the social factor in the study of the Turkic written literary language was mentioned, further research ignores the sociocultural and functional aspects of the literary language and focuses only on the structure of the text, making it impossible to objectively determine the factors that shaped the nature and functions of the literary language.

The scholar points out that the history of the literary language creates its theory and terminology in connection with the study of Russian, Slavic, and Western European literary languages. We suggest that researchers should take into consideration his opinion that the works on the history of English, German, and French literary languages, published in 1983-1986, could be an example of the methodological and typological interpretation of the concept of literary norms: "When studying the history of literary languages, it is necessary to rely on comparative-typological material. Taking into account the research into Germanic, French, and Slavic languages, it is safe to say that the Turkic literary languages obey the same general laws of addition and development as Indo-European literary languages. ... It is time to create a single view on the processes of the language development" [Tenishev, 2006, p. 44]. Realizing the importance of this work, corresponding to the world standards, A. Tenishev presents his theoretical views on the study of the development features of the Turkic and, in particular, the Tatar literary language.

Unlike the spoken language, the written literary language evolves at a certain stage of social development. The laws of the literary language are mainly analyzed in close connection with the period in which writing develops. The scientist's opinion on the possibility of studying folklore, which is created by people and passed down from generation to generation, as an integral part of the literary language - its predecessor - allows us to interpret some issues of the literary language in a new way [Tenishev, 2006, p. 44].

Given that the development of the literary language is inseparable from the events in society, we should take into consideration Tenishev's theoretical views on the study of the literary language development, which can be divided into two major periods: pre-national and national. Both periods are further subdivided and the stages of the development are examined in detail. The first period is particularly difficult to study. In the pre-national period, the written literary language and the universal spoken language differed significantly from each other. In Tenishev's studies of literary languages, great attention is paid to the Old Tatar literary language, which is rooted in the oldest Turkic written literary languages. According to A. Tenishev, at the beginning of the study of the literary language history, it is especially important to focus on the historical and cultural events, the state of cities, the linguistic situation in them, the level of literacy, the work of writers and scientists, and other factors that influenced the development of the literary language [Tenishev, 1979, 80-90; 2006, p. 44]. While studying the complex history of the Tatar literary language, which has ancient written traditions, Tatar scientists rely on A. Tenishev's theoretical ideas. For example, the works on the history of the Tatar literary language, published in recent years by such researchers as I. B. Bashirova [Bəshirova, 1999], and F. Sh. Nurieva, [Nurieva, 2004 ], [Tatar adəbi tel tarikhy, 2015, 2017] are written based on the scientific methodology of A. Tenishev. These works describe the social and economic conditions of a particular period, the linguistic situation, the status and level of use of the literary language, its traditions and novelty.

We can see that pre-national literary languages were transferred from one geographical region to another due to different historical and social circumstances; a certain literary language could perform the function of the literary language far from the region of its origins. In these cases, while the ancient traditional language retained its original features to a certain extent, the dialectical basis of the literary language changed under the influence of the regional spoken language. It is not unnatural that, depending on historical circumstances, a completely foreign language may function as the literary language until the national literary language is established. To prove it, A. Tenishev pointed to the role of the Old Slavic language in the history of the Russian and Slavic languages and 
the role of the Latin language in the development of the German language [Tenishev, 1994, p. 31].

The scholar notes that when studying the history of the literary language, the structure, which indicates its function, should be analyzed holistically and describes five main characteristics that form the essential nature of any literary language and the importance of taking these traits into account in research:

1) processed language, 2) functional and stylistic variability, 3) variability of norms, 4) primacy upon dialects, 5) continuity, traditions [Tenishev, 2006, p. 44]. A. Tenishev also studied written monuments of the ancient Turkic literary language, in particular, the Orkhon-Yenisei, Uyghur scripts, monuments of the Turkic peoples (Tatar, Uzbek, Turkmen, Kyrgyz, Turkish, etc.) [Tenishev, 1976 (O naddialektnom...); 1981, 1987, 1989, 2006, pp. 226-238; 2011, pp. 186-197]. In his article "On the Formation of Ancient Turkic Runic Inscriptions" [Tenishev, 1976 (O naddialektnom...)], A. Tenishev focuses on Koine, a special type of language that emerged at that time; in other words, although the spoken language varied widely among the Turkic tribes, it shows that their written literary form was standardized and superior to a dialectical language. These characteristics that form the main specifics of the literary language are described in the articles, devoted to a detailed study of the language of the poem "Кыйссаи Йосыф" ("Куіssa-i Yosif"), written in the Volga region, which is considered to be the dawn of the Tatar literary language. "When we say 'the language of a poem', we need to picture the structure of the literary language that determines its function as a whole, not the "poetic language" itself or its stylistic features. The literary language is a semi-dialect, a form of language opposed to local dialects. The literary language is considered to be the highest and most prestigious form among them [Tenishev, 1987, pp.133-135; 1994, pp. 31]. Exploring the main features of the poem in terms of these five main characteristics, A. Tenishev reveals the essence of the language of “Кыйссаи Йосыф" and its relation to other Turkic languages.

Adkham Tenishev began his work on the history of the Turkic written literary languages in the context of literary language variants. The scholar conducted his work based on the development of the Tatar literary language. The Tatar language was his sacred native language. In his works on the history of the Tatar literary language, he noted that the literary language, formed in the Volga region, dates back to distant centuries - to the ancient Tur- kic periods, it was processed, had its traditions, continuity, and norms at different levels of its development, and it had been divided into several regional variants until the literary language, which represented the national language of the Tatar people, was formed. This assumption of the scholar, in our opinion, is especially noteworthy with regard to the Old Tatar literary language. A. Tenishev shows how two language streams - Turkic and Oghuz - interweave in Kul Gali's "Кыйссаи Йосыф"; this indicates that the mixed language had existed in the Tatar language environment for quite a long time. "By 'Tatar' I mean the Kipchak elements that include many elements of the Volga Tatars", said the scholar. If this poem by Kul Gali were the only work, it would be possible to speak of some coincidence. But that is not the case here. Other works, dating back to the $13^{\text {th }}-14^{\text {th }}$ centuries, such as "Кисекбаш", "Бәдәвам", "Кыйссаи аук" and others, were written in this mixed language with the elements of the Ugyz language. A. Tenishev considers the language of "Кыйссаи Йосыф" to be one of the local variants of the Old Tatar literary language [Tenishev, 1994, p. 31; 2006, p. 282]. He wrote that the variant of the literary language, influenced by Ugyz, was not the only one existing in the Volga region, but there were other literary types (variants) too. At this point, we should mention the fact that Tenishev defined regional variations as the literary language used by the population in the pre-national period, he noted that it existed in several versions and each literary version had its reader. The scholar also wrote that the Old Tatar literary language consisted of four or five variants and that Old Turkish, Old Azerbaijani, and Old Turkmen had two or three variants. Adkham Tenishev suggested that the Old Tatar literary language was formed based on the KarakhanUyghur, Turkic-Khazar, Ugyz-Turkish, Bulgar, Chagatai, and its own Tatar literary traditions. He argued that the common ground of all variants of the old Tatar literary language was at the base of the Tatar language and united them. He pointed out that Rabguzi's "Кыйсасел-Әнбия" and Akhmet Yahavi's "Хикмәт" are based on the tradition of the Karakhan-Uyghur literary language. He included the poems of Qutb "Хөсрәү вә Ширин" and Harazmi's "Мәхәббәтнамә" in the list of works that preserved the Turkic-Kharazm basis. The epitaph inscriptions of the $13^{\text {th }}-14^{\text {th }}$ century Volga Bolgaria are defined as a literary variant of the Bolgar basis, which indicates that the Chagatai literary tradition formed the basis of numerous Old Tatar literary monuments. [Tenishev, 1983, pp. 
25-31; 2000, pp. 27-31; 2006, p. 282]. It shows that the variants of this literary language existed until the early twentieth century, before the formation of the literary language that reflected the national language, and different writers used the variants they preferred.

A. Tenishev's works also focus on genre and stylistic variability, which is one of the five hallmarks of the literary language. The social use of the literary language led to the creation of its functional system of styles. For example, religious (philosophical-didactic) literature, particular genres of fiction, scientific works, worksheets, features of administrative, academic, and personal correspondence. Its use in different styles requires that the literary language should be considered in close connection with other linguistic phenomena such as dialects and the spoken language. In one of his articles, as a scientist who realized the holistic approach to the studies of the ancient Uyghur language, he focused on the functional and stylistic characteristics of each of the styles of this period (religious and didactic, fictional, scientific works, business papers, personal letters) and identified their features. He suggested that language strata could be differently used: "The consolidation of the elements of the national (dialect) language in the literary language is primarily due to its styles. The elements of the national (dialect) language are more reflected in the style of worksheets and personal correspondence, written in the ancient Uyghur language. However, they take different levels in business correspondence. This depends on the type of a document: elements of dialects, i.e. a living spoken language, are found less in lease agreements, wills, receipts that are subject to longterm storage; the ones that have fewer requirements of standard and norms have more of such elements [Tenishev,1979, pp. 61-78; 2006, pp. 187202]. Functional stratification of language implies different uses of the literary language. A. Tenishev argued that, in this regard, it was advisable to study the ways of the literary language development based on its functional paradigms and that this area should be taken as a basis for studying the history of the literary language [Tenishev, 2006, pp. 187202].

\section{Results}

Adkham Tenishev's scientific work covers a wide range of fields: the historic-comparative grammar of Turkic and Altaic languages, phonetics, morphology, etymology, lexicology, folklore, and the language of ancient Turkic written monu- ments, modern and historical dialectology, and cultural linguistics. Adkham Tenishev's worldfamous achievements in the field of historicalcomparative studies make a significant contribution to the general theory of language, and especially to the theory of the unity of languages. A. Tenishev was highly valued as a founder of the new branch of science in linguistics. Since the 1970s, based on the scientist's theoretical concepts on the history of Turkic literature, a new trend has developed in Turkology - the history of Turkic literary languages. The Tatar language was always his sacred native language. In his works on the history of the Tatar literary language, he defined the methodological principles for studying the Tatar literary language, formed in the Volga region.

Adkham Tenishev thought about the future of Turkology and attached special importance to the preparation of young researchers and scientific guidance. Adkham Tenishev prepared 20 doctors of science and 30 candidates of science. Among his postgraduates and doctoral students there were Tatar, Bashkir, Russian, Turkish, Kazakh, Uzbek, Turkmen, Yakut, Uyghur, Buryat, Kalmyk, Karakalpak, Karachay, Balkar, Azerbaijani, Chuvash, and Crimean scientists, representatives of European countries. The scholar's disciples are known for their important discoveries in the field of linguistics, they created their own scientific trends and educated their successors. Adkham Tenishev remained loyal to his native nation - the Tatar people: he was a scientific supervisor, official evaluator, and scientific editor of their books their teacher and mentor. The famous Tatar scholars F. Y. Yusupov, F. S. Khakimzyanov, F. Sattarov, R. A. Yusupov, F. S. Safiullina, L. K. Bayramova, F. G. Garipova, I. M. Nizamov, F. Sh. Nurieva, E. H. Kadyrova, R. A. Zakirov and many others who received the A. Tenishev's blessing in the scientific field, proved to be individuals who have tirelessly served the Tatar world, and are known as the creators of different scientific schools. There is a boundless respect in the hearts of the scientists who studied at the scientific school of Adkham Tenishev, their mentor who provided them with all possible assistance. After the death of Adkham Tenishev, the honorary Academician of the Academy of Sciences of the Republic of Bashkortostan, a three-volume collection "Сайланма хезмәтләр" ("Selected Works") was published, it included the articles, published in different years in various publications and many of his unpublished works [Izbrannye trudy, 2006, 2006, 2011]. The Ural-Altai Department of the Institute 
of Linguistics of the Russian Academy of Sciences in Moscow, Kazan Federal University and other Turkic-speaking state scientific organizations regularly hold scientific conferences, dedicated to the outstanding scientist, his legacy, and scientific achievements in the study of languages.

\section{Conclusions}

A new stage of studying the history of the Turkic literary languages began under the guidance of the outstanding turkologist, our respected compatriot Adkham Rakhimovich Tenishev.

The current stage of research is characterized by the creation of works, based on the scholar's theoretical ideas, which have significant scientific value in the light of new achievements in linguistics.

The nature and functions of the literary language are a complex phenomenon, its linguistic basis is its traditions and social life, reflected in written monuments. In his works, A. Tenishev identified the following aspects, which became the basis for the study of the Turkic literary language:

1) The study of the history of the Turkic languages should be conducted in three directions: a) the historical grammar of the national language, b) the historical grammar of the literary language, c) the history of the literary language.

2) There exists typological similarity in the development of literary languages of the world.

3) The canons of the literary language are related to the period of the invention of writing; folklore can be studied as the predecessor and the integral part of the literary language.

4) The study of the general structure of language and the study of the language of written works should be conducted apart from each other and explored in different branches of science.

5) Five main characteristics that form the essential nature of the literary language are: 1) processed language, 2) functional and stylistic variability, 3) variability of norms, 4) primacy upon dialects, 5) continuity, traditions.

The principles, related to the study of the literary language, its nature and history, proposed by A. Tenishev, have been fully accepted in linguistics, and both the history of the Turkic literary language and the actual history of the Tatar literary language are studied based on his theoretical ideas. The work of the outstanding scientist Adkham Tenishev was highly appreciated in Russian science and the world's Turkology, and his legacy still determines the academic level of Turkic linguistics.

\section{References}

Bəshirova, I. B. (1999). XIX gasyr akhyry - XX ŭez bashy Tatar adəbi tele: isem kategorialore həm figyl' naklonenielarenda adabi norma, norma variantlylygy həm funktsional' - stilistik variantlylyk [The Late Nineteenth - Early Twentieth Century Tatar Literary Language: Literary Norms in Noun Categories and Verb Moods, Norm Variability and Functional-Stylistic Variability]. 576 p. Kazan, KDTU nəshr. (In Tatar)

Dybo, A. V. (201). Edkhiam Rakhimovich Tenishev [Adhyam Rahimovich Tenishev]. Iazykove urovni i ikh analiz. 184 p. Kazan', izd-vo Tatarskogo gos. gumanitarnogo instituta. (In Russian)

Khisamova, F. M. (2003). Tugan tel ham millat iazmyshy [The Native Language and the Destiny of the Nation]. Tatarika. No. 1, pp. 23-35. (In Tatar)

Kirsanov, V. I. (1980). Krupnyi vostokovedtiurkolog [A Major Orientalist-Turkologist]. Issledovanie iazyka drevnepis'mennykh pamiatnikov. 160 p. Kazan'. (In Russian)

Iazyki mira: Tyurkskiye iazyki (1997) [Languages of the World: Türkic Languages]. 543 p. Bishkek. (In Russian)

Nurieva, F. Sh. (2004). Istoricheskie $i$ lingvisticheskie usloviia formirovaniia tyurkotatarskogo literaturnogo iazyka zoltoordynskogo perioda [Historical and Linguistic Conditions for the Formation of the Turkic-Tatar Literary Language of the Golden-Horde Period]. 376 p. Kazan', Kazan. Gos. un-t. (In Russian)

Nurieva, F. Sh. (201). Tatar zyialylarynyң zatlysy [A Prominenet Representative of Tatar Intellectuals]. iazykovyye urovni i ikh analiz. 184 p. Kazan', izd-vo Tatarskogo gos. gumanitarnogo institute. (In Russian)

Nurieva, F. Sh., Kurbatov, Kh. R. (2003). Tenishev ta, Eniki do, Kuprin da - iakyn tugannar [Close Relationship between Tenishev, Eniky, and Kuprin]. Tatarstan. No. 8, pp .46-48. (In Russian)

Sravnitel'no-istoricheskaia grammatika tiurkskikh iazykov (1997) [Comparative-Historical Grammar of the Turkic Languages]. Leksika. 799 p. Moscow. (In Russian)

Sravnitel'no-istoricheskaia grammatika tiurkskikh iazykov (2001) [Comparative-Historical Grammar of the Turkic Languages]. Leksika. T.4. 2-ye izd. 822 p. Moscow, "Nauka" (In Russian)

Sravnitel'no-istoricheskaia grammatika tiurkskikh iazykov (1988) [Comparative-Historical Grammar of the Turkic Languages]. Morfologiia. 560 p. Moscow, "Nauka". (In Russian)

Sravnitel'no-istoricheskaia grammatika tiurkskikh iazykov (2006) [Comparative-Historical Grammar of the Turkic Languages]. Pratyurkskii iazyk-osnova. Kartina mira pratyurkskogo etnosa po dannymiyazyka.T.6. 908 p. Moscow, "Nauka". (In Russian)

Sravnitel'no-istoricheskaia grammatika tiurkskikh iazykov (2002) [Comparative-Historical Grammar of the Turkic Languages]. Regional'ne rekonstruktsii. T.5. 767 p. Moscow, "Nauka". (In Russian) 
Sravnitel'no-istoricheskaia grammatika tiurkskikh iazykov (1984) [Comparative-Historical Grammar of the Turkic Languages]. Fonetika. T. 1. 484 p. Moscow. (In Russian)

Tatar adabi tele tarikhy (XIII gasyr - XX ŭөz bashy). II t.: Morfologiia. Grammatik kategoriialornew structursubstatsional' Yzencholege hom funktsional'-stilistik momkinleklare: iazma traditsiialar, norma hom variantlylyk (2017) [History of the Tatar Literary Language (the $13^{\text {th }}$ century-early $20^{\text {th }}$ centuries). Volume II: Morphology. Structural-Substantive Features and Functional-Stylistic Capabilities of Grammatical Categories: Written Traditions, Norms, and Variability]. 888 p. Kazan, TəKhSI. (In Tatar)

Tatars adabi tele tarihy (XIII gasyr - XX oz bashy) I t.: Fonetika. Grafika: iazma traditsialor, norma hom variantlylyk (2015) [History of the Tatar Literary Language (the $13^{\text {th }}$-early $20^{\text {th }}$ centuries). Volume I: Phonetics. Graphics: Written Traditions, Norms, and Variability]. 696 p. Kazan, TӘKhSI. (In Tatar)

Tenishev, Ә. R. (1994). Kyissai Yosif poemasyny, tele [The Language of the Poem "Kissa-i Yusuf"]. Miras. No. 1, pp. 30-31. (In Tatar)

Tenishev, E. R. (2006). Izbrannye Trudy [Selected Works]. Kniga vtoraia. 380 p. Ufa, Gilem. (In Russian)

Tenishev, E. R. (2006). Izbrannye Trudy [Selected Works]. Kniga pervaia. 304 p. Ufa, Gilem. (In Russian)

Tenishev, E. R. (2011). Izbrannye Trudy [Selected Works]. Kniga tret'ia. 256 p. Ufa, IIYAL UNTS RAN. (In Russian)

Tenishev, E. R. (2000). K istorii literaturnogo iazyka $i$ kul'tury tatarskogo naroda [On the History of the Literary Language and Culture of the Tatar People]. Vestnik AN RB . T.5, No. 1, pp. 27-31. (In Russian)

Tenishev, E. R. (1983). Novyi spisok Rabguzi [The New List of Rabguzi]. Istoriko-lingvisticheskii analiz staropis'mennykh pamiatnikov. Pp. 25-31. Kazan'. (In Russian)

Tenishev, E. R. (1989). O kirgizskom literaturnom iazyke $v$ donatsional'nyi period [On the Kyrgyz Literary Language in the Pre-National Period]. Voprosy iazykoznaniia. No. 5, pp. 32-40. (In Russian)

Tenishev, E. R. (1981). O naddialektnoi prirode iazyka karakhanidsko-uigurskikh pis'mennykh pamyatnikov [On the Supra-Dialectal Nature of the Language of the Karakhanid-Uighur Written Monuments]. Tipy naddialektnykh form iazyka. Pp. 266-277. Moscow. (In Russian)

Tenishev, E. R. (1976). O naddialektnom kharaktere iazyka tyurkskikh runicheskikh pamiatnikov
[On the Supra-Dialectal Nature of the Language of the Türkic Runic Monuments]. Turcologica . Pp. 230-232. Moscow. (In Russian)

Tenishev, E. R. (1976). O naddialektnom kharaktere iazyka tyurkskikh runicheskikh pamiatnikov [On the Supra-Dialectal Nature of the Language of the Türkic Runic Monuments]. Turkologika. Pp. 164-172. Leningrad. (In Russian)

Tenishev, E. R. (1976). O postroenii istorii narodno-razgovornogo i literaturnogo iazykov [On the Construction of the History of Folk-Spoken and Literary Languages]. Tiurkologicheskie issledovaniia. Pp. 230232. Moscow. (In Russian)

Tenishev, E. R. (1987). O iazyke poemy "Kyissa-i Yosuf" Kul Gali [On the Language of the Poem “Kyissa-i Yosuf” by Kul Gali]. Poet-gumanist Kul Gali. Pp.133-137. Kazan', Tat.kn. izd-vo. (In Russian)

Tenishev, E. R. (1988). Printsipy sostavleniia istoricheskikh grammatik $i$ istorii literaturnykh iazykov [Principles for the Compilation of Historical Grammars and the History of Literary Languages]. Sovetskaia tiurkologiia. No. 3, pp. 67-78. (In Russian)

Tenishev, E. R. (1996). Rodoslovnaia Tenishevykh [The Tenishevs' Pedigree]. Rossiiskaia provintsiia XVIII-XX vv. Kn. 1. Penza, pp. 397-401. (In Russian)

Tenishev, E. R. (1976). Stroi salarskogo iazyka [The Structure of the Salar Language]. 575 p. Moscow. (In Russian)

Tenishev, E. R. (1976). Stroi saryg-uigurskogo iazyka [The Structure of the Saryg-Yugur Language]. 307 p. Moscow. (In Russian)

Tenishev, E. R. (1995). U tyurkskikh narodov Kitaia [Among the Turkic Peoples of China]. (Dnevniki 1956-1958 gg.). 240 p. Moscow. (In Russian)

Tenishev, E. R. (1977). Funktsional'nostilisticheskaia kharakteristika drevneuigurskogo literaturnogo iazyka [Functional and Stylistic Characteristics of the Ancient Uigur Literary Language]. Sotsial'naia i funktsional'naia differentsiatsiia literaturnykh iazykov. Pp. 61-78. Moscow. (In Russian)

Tenishev, E. R. (1987). Iazyk proizvedenii Davletmukhammeda $i$ Makhtumkuli Fragi [The Language of Works by Davletmukhammed and Makhtumkuli Fraghi]. Sushchnost' razvitie i funktsii iazyka. Pp. 196-202. Moscow. (In Russian)

Tenishev, E. R. (1979). Iazyki drevne- $i$ srednetiurkskikh pamiatnikov $v$ funktsional'nom aspekte [Languages of Ancient and Middle Türkic Monuments in the Functional Aspect]. Voprosy iazykoznaniia, No. 2, pp. 80-90. (In Russian) 


\title{
КУРЕНЕКЛЕ ТЮРКОЛОГ-ГАЛИМ ӘДИӘМ РӘХИМ УЛЫ ТЕНИШЕВНЫН ТӨРКИ ҺӘМ ТАТАР ӘДӘБИ ТЕЛ ТАРИХЫН ӨЙРӘНУ ӨЛКӘСЕНДӘГЕ ЭШЧӘНЛЕГЕ
}

\author{
Фәнүзә Шәкүр кызы Нуриева, \\ Казан федераль университеты, \\ Россия, 420008, Казан ш., Кремль ур., 18 нче йорт, \\ fanuzanurieva@yandex.ru.
}

\begin{abstract}
Мәкалә дөньякүләм танылган галим, төрки тел белеменең иң күренекле шәхесләреннән берсе Әдһәм Рәхим улы Тенишевның (24.04.1921-11.07.2004) төрки һәм татар әдәби теле тарихы өлкәсендәге эшчәнлеген өйрәнүгә багышлана. Галимнең хезмәтләре, лингвистик фикере хәзерге тел белеме теориясенә һәм татар тел гыйлеме үсешенә керткән өлеше яктылыгында анализлана.

Ә.Р. Тенишевның борынгы төрки язма истәлекләр, Үзәк Азия халыкларының хәзерге телләре, чагыштырма-тарихи грамматика, төрки телләр тарихын өйрәнү өлкәсендәге тикшеренүләренә гомуми күзәтү ясалды. Төрки телләрнең тарихын чагыштырма планда тикшергән алты томнан торган күмәк хезмәтнең бу юнәлештәге эшчәнлегенең төрки халыкларның бай мирасын өйрәнү, аерым төрки телләрнең тарихи үсеш-үзгәрешен билгеләү ягыннан әһәмияте күрсәтелде. Мәкаләдә Ә.Р. Тенишевның дөнья фәне казанышларына таянып, төрки әдәби тел тарихы фәнен нигезләгән гомумтеоретик карашлары барланды, әдәби телнең вазифасын барлыкка китерә торган билге-шартлар тәфсилле анализланды. Галимнең хезмәтләренең хәзерге татар әдәби тел тарихын язу өчен фәнни-методик яктан зур мөмкинлекләр ачуы, алар нигезендә күп мәсьәләләрне аңлату, жавап табу мөмкинлекләре билгеләнде.
\end{abstract}

Төп төшенчәләр: Әдһәм Рәхим улы Тенишев, тюркология, татар теле, төрки телләр, әдәби тел тарихы.

\section{Кереш}

Тел гыйлемендә халыкның тарихы һәм мәдәнияте белән тыгыз бәйләнештә торган тел тарихы фәне яшәп килә. Филологиядә 19601970 нче елларда тел тарихының бер тармагы буларак, әдәби тел тарихы дип аталган яңа фән юнәлеше формалаша. Төрки тел белемендә әдәби тел тарихы фәнен теоретик нигезләүче булып Ә.Р.Тенишев тора. Әдһәм Рәхим улы 40 ел дәвамында алтаистик эзләнүләр үзәге булган Мәскәу шәһәрендә Россия фәннәр академиясенең Тел белеме институтында төрки һәм монгол телләре бүлеген житәкләгән, Россиянең мәшһүр галиме, дөньякүләм танылган тюрколог. Ә.Р. Тенишевның хезмәтләрендә урын алган әдәби тел тарихын үзенә якын фән тармакларыннан - тарихи грамматикадан аерып торган сыйфатларын, әдәби телнең табигатен һәм вазифаларын билгели торган төп фәнни принципларын ачыклау эшебезнең актуальлеген тәшкил итә.

Чыннан да, халыкларның тарихлары икътисад үсешендә, сәяси вакыйгаларда гына түгел, гасырлар дәвамында тудырылган күпсанлы һәм кыйммәтле мәдәни мирасында да. Ә.Р.Тенишев ачыклаган төрки әдәби телнең асыл табигатен барлыкка китерә торган билгеләрне: эшкәртелгән, норма һәм функциональстилистик вариантлылыкка ия булу, традициясе-дәвамчанлыгы күренешләрен әдәби ядкарьләр үрнәгендә яктырту эшебезнең максаты булып тора. Галимнең киңкырлы эшчәнлеге В.И. Кирсанов [Кирсанов, 1980, б. 325], А.В. Дыбо [Дыбо, 2001, б. 6-18], Д.М. Насилов [Насилов, 2006, б. 6-12], И.Б. Бәширова [Бәширова, 1999, б. 37-38], Ф.Ш. Нуриева [Нуриева, 2001, б. 18-22; 2004, б. 1945] хезмәтләрендә яктыртылса да, Ә.Р. Тенишевның төрки әдәби тел тарихы өлкәсенә караган эшчәнлегенә махсус игътибар ителмәде. Мәкаләбездә Әдһәм Рәхим улы Тенишевның әдәби тел тарихын өйрәнүдә ирешкән казанышларын барлап, аларның татар әдәби тел тарихын өйрәнүдә, үсеш-үзгәрешен, вариантлылыгын билгеләүдә кулланылу мөмкинлекләрен билгеләү эшебезнең яңалыгын тәшкил итә. Ә.Тенишев мәкаләсендә әдәби тел тарихының Үз фәненә хас метод-алымнар белән тикшерелергә тиешлеген күрсәтеп, бер генә төрки телнең дә бу нигездә өйрәнелмәве хакында фикер әйтелгән иде [Тенишев, 1988, б. 44]. Бүгенге көндә иске татар телендә язылган 
барлык чыганаклар да диярлек галимнәр тарафыннан тикшерелгән, фәнни әйләнешкә кертелгән. Соңгы ике дистә ел эчендә Ә.Р.Тенишевның теоретик фикерләренә, фәнни методикасына нигезләнеп, татар әдәби тел тарихын өйрәнгән И.Б. Бәширова [Бәширова, 1999], Ф.Ш. Нуриева [Нуриева, 2004], коллектив хезмәт [Татар әдәби тел тарихы, 2015, 2017] hәм башка галимнәрнең монографияләре нәшер ителде. Әлеге хезмәтләрдә язма традициянең, норманың саклану дәрәжәсе ачыкланган, иске татар әдәби теленең үсеш-үзгәреше һәм әдәби телнең жирле вариантлары тикшерелгән.

Хезмәтне язу барышында түбәндәге анализ ысуллары кулланылды: галим хезмәтләрендә китерелгән фактларны табу гомумлингвистик тасвирлау һәм барлау ысулына нигезләнде; чорга бәйле әдәби нормаларны, әдәби тел вариантларын чагыштырганда, чагыштырматарихи метод кулланылды.

\section{Төп өлеш. Галимнең тормышы һәм фәнни эшчәнлегенә кыскача күзәту}

Тынгысыз, киң колачлы галим Әдһәм Рәхим улы Тенишев үзенең чыгышы белән XV-XVI гасырларда яшәгән кенәз Тенишевлар нәселенә барып тоташа. Бу кенәзлекнең күп кенә оныклары тора-бара христиан динен кабул итә, ə Ишмөхәммәт буыныннан килгәннәре həм алардан туган Шөкер-Али тармагы мөселман динендә кала. 1921 елның 24 апрелендә Пенза шәһәрендә дөньяга килгән Әдһәм Рәхим улы шул Шөкер-Али тармагыннан. Татар кенәзләре элек-электән хәрби хезмәттә батырлык күрсәткәне һәм фәндә уңышлы эш башкарганнары өчен хөкүмәттән бүләк алганнар. Мәсәлән, патша Василий Иванович Тениш Кугушевка зур жир биләмәләре биргән. Бу жирләр соңыннан аларның уллары Еники Ямашка һәм Исәшкә күчкән. Атаклы татар язучысы Әмирхан Еники шушы тармактан, алар - Әдһәм Тенишев белән нәселдәшләр. Ишмөхәммәт һәм Еники нәселеннән яңа дәвергә байтак күренекле талант ияләре үсеп чыккан. Мәсәлән, Колынчык Еникиев - атаклы рус язучысы А.И. Купринның бабасы. Ишмөхәммәт нәселенең Пенза төбәгендә яшәгән ундүрт буыны билгеле. Бу нәсел татар дөньясына билгеле дин галиме Муса Бигиевне, язучы Заһир Бигиевне, татарның беренче революционерларының берсе, язучы Гафур Коләхмәтовны бирүе белән дә билгеле [Тенишев, 1996, б. 397-401; Нуриева, Курбатов 2003, б. 46-47].
Булачак галим татар мәдәниятен үстерүгә үзләреннән зур өлеш керткән, белемне югары бәяләгән гаиләдә тәрбияләнә, шәхси китапханәләрендәге гарәп, фарсы, рус китапларын, гарәп графикасы белән язылган борынгы кулъязмаларны укып-тыңлап үсә. Әдһәм Тенишевның әтисе Рәхим Мөбин улы һәм әнисе Әминә Алим кызы шулай ук татар мәдәниятен үстерүгә күп көч салган фидакяр затлар була. Әтисе Казан реаль училищесында белем алган, татар халкының танылган шәхесләре Г.Тукай белән аралашкан, Г.Камал, Ф.Әмирхан, Г.Коләхмәтовлар белән татар спектакльләре уйнаган. Галимнең әбисе Хәбибжамал абыстайга танылган дин галиме Ризаэддин Фәхретдинов “Мәшһүр хатыннар" китабында аерым бүлек багышлаган [Нуриева, 2001, б. 19].

Морзалар нәселеннән чыккан, югары белем hәм тәрбия алган әти-әнисенең, якыннарының үз акыл-көчен халыкка хезмәт итүгә багышлаганын күреп үскән Әдһәм Рәхим улының күп сыйфатлары гаилә үрнәгеннән килә булыр. Гомерен төрки телләрне өйрәнүгә багышлау фикере кайчан тугандыр - монысы безгә билгесез, ләкин мәктәпне тәмамлап, техник юлны сайлаган Әдһәм Рәхим улы урау юллар үтеп, 1941 нче елда Ленинград университетының шәрык телләре факультетына укырга керә, аны 1945 нче елда тәмамлый, төрки телләр белгечлеге ала. Аның укытучылары - дөньяга мәшһүр галимнәр Н.К. Дмитриев, А.Н. Кононов, Е.Э. Бертельс, И.Ю. Крачковский була. Әдһәм Рәхим улының фәнни эшчәнлегендә якташыбыз, бөек галим С.Е. Маловның зур роль уйнаганын аерып әйтергә кирәк. 1953 нче елда ул С.Е. Малов житәкчелегендә борынгы уйгыр язма әдәби тел истәлеге “Алтун Ярук” буенча кандидатлык диссертациясен яклый. Яшь белгеч 1954 елда Мәскәү шәһәрендә урнашкан СССР Фәннәр академиясенең Тел белеме институтына эшкә билгеләнә. Бераздан (1956 ел) Кытай Фәннәр академиясе соравы буенча төрки тел белгечләре әзерләү өчен өч елга Кытайга жибәрелә. Бу чор эшчәнлеге бик интенсив, киң колачлы бара. Ул төрек теле укыта, төрки телләр белгечләре - аспирантлар әзерләүгә житди игътибар бирә. Соңыннан аның укучылары зур галимнәр булып китәләр. Аның төрки телләрне өйрәнүгә багышланган ике китабын кытай теленә тәржемә итеп бастырып чыгаралар. Читтә эшләгән вакытта ул Тибетның төрки халыклар яшәгән өлкәләрендә жанлы сөйләмне өйрәнү өчен фәнни сәфәрләргә чыга, жентекле язмалар-көндәлек алып бара. 
1959 елда Мәскәүгә кайткач, Кытайдагы эшчәнлеге нәтижәсендә Синьцзян, Цинхай, Ганьсу төбәкләрендә тупланган экспедиция материалларын эшкәртеп бастырган күпсанлы мәкаләләре, ике китабы дөнья күрә. Әдһәм Тенишев - салар төркиләре тарихын фәнни дәрәжәдә беренче булып өйрәнгән галим. 1969 елда ул салар теленнән туплаган материаллары нигезендә "Строй саларского языка" дигән темага докторлык диссертациясен уңышлы яклый. Хезмәттә бу көнгә кадәр уйгыр, төрекмән телләренең бер диалекты итеп каралган салар теленең мөстәкыйль тел булуы исбатлана, киң яссылыкта тарихи, этногенетик, чагыштырма-лингвистик материаллар белән раслана. 1976 елда әлеге хезмәт аерым китап булып басыла. Яшь профессорның 1976 елда “Строй сарыг-югурского языка" монографиясе дә нәшер ителә, беренче бүлектә сары уйгырларың, икенче бүлектә шира уйгырларның телләре, фонетикасы һәм сүзлеге Ә. Тенишевка хас төгәллек белән эшләнгән [Тенишев, 1976 (Строй...]. Әдһәм Рәхим улының фәнни тикшерүләренең яңалыгы һәм тирәнлеге әһәмиятле булган кебек, алдагы буын тикшеручеләр өчен диалектны аерып чыгару принципларын һәм критерийларын билгеләве белән хезмәт аеруча кыйммәтле. Аның Кытайда эшләу дәверендә алып барган этнографик материалларга бай көндәлеге кырык елдан соң нәшер ителде [Тенишев, 1995].

1963 нче елда Россия Фәннәр академиясенең Тел институтына төрки телләр бүлегенең мөдире итеп билгеләнгәч, Әдһәм Рәхим улы бөтен гыйльми мәсьәләләрне барлап, үзенең мәсләктәшләре белән бергә коллектив хезмәтләр язуны максат итеп куя. Аның фәнни һәм административ житәкчелегендә дөньякүләм әһәмияткә ирешкән алтаистика, бигрәк тә, төрки телләрне чагыштырма-тарихи юнәлештә өйрәнгән фундаменталь хезмәтләр нәшер ителә башлый. Галим куйган бурычларның киң һәм күпкырлы булуы, күтәрелгән мәсьәләләрнең фәнни тирәнлеге һәм яңалыгы Әдһәм Рәхим улы Тенишевка тюркология фәненең мәшһүр галиме данын китерә. Киң гыйльми фикерле Әдһәм Рәхим улы - шул белемен, мәгълүматын башкаларга өләшүче кешелекле һәм могтәбәр зат бүлек белән 40 ел житәкчелек итә, жылы фәнни мохит булдыра. Ул житәкләгән төрки hәм монгол телләре бүлегендә төрки телләрнең этимологик сүзлеге әзерләнә һәм бастырыла башлый, “Дөнья телләре” программалары кысаларында “Төрки телләр” дигән энцикло- педик томлык әзерләнә һәм бастырып чыгарыла (ул аның баш мөхәррире һәм күп кенә мәкаләләрнең авторы [Языки мира, 1997]. Ә.Р. Тенишев остазы Н.К. Дмитриевның фәнни мирасын лаеклы дәвам итүче, тәжрибәле житәкче буларак бәяләнә [Дыбо, 2001, б. 6-18]. Төрки тел фәненең казанышларына таянып, борынгы төрки тел күренешләрен реконструкцияләү каралган “Төрки телләрнең тарихичагыштырма грамматикасы” дип аталган алты томлыкның программасы төзелеп, бүлек галимнәре белән аерым томнарны әзерләү һәм бастыру юнәлешендә нәтижәле эш алып барыла. Хезмәтнең беренче дүрт томы (“Фонетика” [Сравнительно-историческая грамматика, 1984], "Морфология" [Сравнительно-историческая грамматика, 1989], “Лексика" [Сравнительно-историческая грамматика, 1997; 2001]) галимнең турыдан-туры катнашлыгында дөнья күрә. Әдһәм Тенишев авторларны оештырып, фикер уртаклыгына ирешеп кенә калмый, аерым бүлекчәләрне дә яза. Әлеге томнарда чагыштырмалы-тарихи ысул кулланылып, иң борынгы төрки нигез тел реконструкцияләнә. Танылган галимә Ф.М. Хисамова сүзләре белән әйткәндә, "Хәзерге заман лингвистика фәне югарылыгында эшләнгән әлеге капиталь хезмәтләрнең чыгуы төрки телләр тарихын гомуми планда өйрәнү өчен генә түгел, ә аерым төрки телләрнең грамматик төзелешенә хас кайбер мәсьәләләрне дә яңача фәнни нигездә аңлатырга мөмкинлек бирә. Традицион тюркология фәнендә, мәсәлән, кыпчак төркеменә кергән телләр, шул исәптән татар теле дә, тарихи яктан күп кенә структур үзгәрешләр кичергән «яңа» телләрдән санала иде. Борынгы hәм иң борынгы төрки нигез телне яңача фәнни нигездә реконструкцияләү нәтижәләре күп кенә очракларда татар теленең борынгы нигез телгә шактый якын торуын дәлилләргә дә мөмкинлек бирә” [Хисамова, 2013, б. 33]. Грамматиканың өч томы басылып чыгу белән Әдһәм Тенишев Азия мөселманнар комитетының Әл-Бохари вакыфы бүләгенә лаек була. Бу хезмәтләрнең әһәмиятен бөтен шәрык дөньясы таный.

Грамматиканың бишенче томы "Региональные реконструкции" [Сравнительно-историческая грамматика, 2002] Ә.Р. Тенишев житәкчелегендә һәм катнашы белән әзерләнә. Биредә тикшеренүләр хәзерге заман төрки телләре һәм диалектларын, шулай ук язма истәлекләрне генетик төркемнәр нигезендә торгызу юнәлешендә алып барыла. Хезмәттә аерым төрки телләрнең тарихы конкретлаштырыла, тарихи 
үсеш вакытында аларның диалектлар системасының кисешүе яки таркалуы, үсеш-үзгәреше күрсәтелә, пратөрки (әүвәлге) чор төгәл торгызыла (реконструкцияләнә). Әмма галим тарихи грамматиканың соңгы - алтынчы “Пратюркский язык. Картина мира пратюрков" [Сравнительно-историческая грамматика, 2006] томының басылып чыгып, тюркология фәнен иң югары баскычка күтәргән хезмәт буларак бәя алуын күрергә өлгермәде. 2004 елның 11 нче июлендә бу дөньядан бакыйга күчте.

Тенишев Әдһәм Рәхим улы житәкчелек иткән бүлектә төрки телләрдән тыш, монгол телләрен тарихи юнәлештә тикшерү, монгол теленең тулы сүзлеген төзү эшләренә игътибар ителә.

1977 елда Әдһәм Рәхим улы Тенишев халыкара ЮНЕСКО оешмасы карамагында булган Европа лингвистик атласының төрки телләр буенча жаваплы редакторы итеп билгеләнгәч, төрки диалектологиясен өйрәнү перспективасына бәйле мәкаләләре дөнья күрә. 1987 елда академик А.Н. Кононов вафатыннан соң, Россия тюркология комитеты житәкчесе итеп раслана, Россия тюркология фәне үсешенең юнәлешен билгеләү, милли республикаларда кадрлар әзерләү, фәннең мөһим өлкәләрен колачлаган фәнни хезмәтләр яздыру, аларны нәшер итү, ел саен Тюркологик пленум жыю, гыйльми конференцияләр уздыру эшләре дә аның жаваплылыгына күчә. Тюркология фәнендә иң абруйлы “Советская Тюркология" журналы 1970 елның 1 апрелендә нәшер ителә башлаган. Фәннәр Академиясенең басма органы булган әлеге журналны житәкләү дә аның жилкәсенә төшә. Тюрколог галим 1990 елда Россия культура фондында “Евразия халыклары дастаны” редакторы итеп билгеләнгәч, аның редакторлыгында кыргыз, карачайбалкар, карел-фин, бурят һәм башка бик күп халыкларның дастаннары нәшер ителә, дөньякүләм танылу ала. 1995 елда “Манас"ның 1000 еллыгы халыкара бәйрәменә аның өченче, дүртенче томнары әзерләп бастырыла. Әдһәм Рәхим улы Кырымда яшәүче төрки халыкларын - кырым татарлары, караим, кырымчак телләрен, аларның тарихын жентекләп өйрәнеп, саллы хезмәтләр бастыра.

Галимнең филология фәненең берничә зур тармагында алып барган фидакяр хезмәте дөньякүләм югары бәясен ала, Тенишев Ә.Р. 1982 елда Төрек Тел Курумуның Шәрәф иясе, “Фин-угыр жәмгыяте" әгъза-мөхбире итеп сайлана. 1998 елда Төркия дәүләт башлыгы
Сөләйман Демирел галим Әдһәм Рәхим улы Тенишевны Likyat nişanı медале белән бүләкли.

\section{Әдһәм Рәхим улы Тенишевның төрки} һәм татар әдәби тел тарихын өйрәну өлкәсендәге эшчәнлеге. Тирән белемле Әдһәм Рәхим улының фәнни эшчәнлеге күп өлкәләрне колачлый. Аның төп хезмәтләрен шартлы рәвештә дүрт юнәлешкә бүлеп карарга мөмкин: Үзәк Азия халыкларының хәзерге телләре, борынгы төрки язма истәлекләр, чагыштырматарихи грамматика, төрки телләр тарихы.

Мәкаләбездә галимнең фәнни юнәлешләреннән берсе - төрки язма әдәби истәлекләрен өйрәнү белән бәйле эшчәнлеген яктыртуга игътибар бирербез.

Тел белемендә ХX гасырның 60-70 нче елларында телне структур һәм функциональстилистик яктан өйрәну урын ала, тел нормаларының һәм стильләрнең төзелешен һәм үсешен өйрәнә торган тармак - әдәби тел тарихы фәне формалаша. Төрки тел белемендә әлеге юнәлешнең төп принципларын теоретик нигезләүче галим - Әдһәм Рәхим улы Тенишев. Телләрнең үсеш тарихын төгәл күз алдына китеру, гомуми һәм хосусый билгеләрен дөрес итеп аерып чыгару максатыннан, Ә.Р.Тенишев хезмәтләрендә төрки телләр тарихын өч юнәлештә өйрәнү мөмкинлеге билгеләнә: 1) милли телнең тарихи грамматикасы, 2) әдәби телнең тарихи грамматикасы, 3) әдәби тел тарихы. Әлеге юнәлешләр өйрәнүнең максаты, ысуллары һәм тикшеру өчен нигез булган чыганаклар буенча да бер-берсеннән шактый аерылып тора. һәр юнәлештә тел берәмлекләренең үз системасын яшәтә торган, үзләренә генә хас булган бәйләнеш-мөнәсәбәтләре ачыкланган, төп өйрәнү принциплары бирелгән [Тенишев, 1988, б. 67-78]. Тарихи грамматикада халык теленең тарихы төзелеше буенча, ягъни структур яктан өйрәнелсә, әдәби тел тарихы фәне борынгыдан килгән һәртөрле язма истәлекләргә нигезләнеп, гомумтөрки телләр төркемендә яки конкрет бер телдә формалашу тарихын, әдәби телнең чорларга бүленешен, кулланылыш үзенчәлекләрен өйрәнә. Әдәби тел тарихында тел нормаларының һәм стильләрнең үсеш-үзгәреше тарихи-ижтимагый вәзгыятькә бәйле рәвештә, ягъни функциональ юнәлештә тикшерелә. Әдәби тел тарихына мөнәсәбәттә тел элементларының кайсы төркем төрки телдән булганын гына түгел, язма әсәрдәге һәр лексик, морфологик һәм синтаксик чараларның текстта нинди функция үтәүләренә, матур 
әдәбият текстында поэтик алымнарның кулланылуына, поэтик функциясенә игътибар итү мөһим. Максаты һәм юнәлешләре төрле булуга карамастан, халыкның тарихы һәм мәдәниятенә мөнәсәбәттә әдәби тел тарихы һәм тарихи грамматика бер-берсе белән тыгыз бәйләнештә тора. Шушы үзенчәлекне истә тотып, Әдһәм Рәхим улы Тенишев төрки телләр тарихын өйрәнгәндә, сөйләмә һәм язма әдәби телнең табигате һәм вазифасы һич тә бер үк төрле була алмавын, шуңа күрә язма әдәби тел тарихын үзенә аерым, сөйләм теленең структурасын шулай ук аерым тикшеру зарурлыгына аеруча игътибар итә. Борынгы язма истәлекләрдә чагылыш тапкан әдәби тел, кагыйдә буларак, сөйләм теле белән тәңгәл килми, чөнки истәлекләр телендә борынгы язма традицияләрнең дәвамчанлыгы саклана. Галимнең барлык хезмәтләрендә язма әсәрләрнең телен hәм гомуми тел төзелешен өйрәнгәндә, бу тармаклар тарихын берсен икенчесеннән аерып карарга кирәклегенә басым ясала [Тенишев, 1976 (О построении...), б. 230-232; 1988, б. 67$78]$.

Төрки әдәби телне башлап өйрәнгән тюркологлар В.В. Радлов, С.Е. Малов хезмәтләрендә төрки язма әдәби телне өйрәнүдә аның ижтимагый табигате истә тотылса да, алга таба тикшеренүләрдә Әдһәм Рәхим улы әдәби телнең социаль-ижтимагый hәм функциональ табигатенә игътибар ителмичә, текстның структур төзелешен тикшерүгә өстенлек бирелүен həм әдәби телнең табигатен һәм вазифасын барлыкка китерә торган Үзенчәлекләрнең объектив яктыртыла алмавын тәнкыйди билгеләп үтә.

Әдәби тел тарихы фәне үзенең теориясе, терминологиясе белән рус, славян, көнбатыш европа әдәби телләрен өйрәнүгә бәйле үсеш ала, дип күрсәтә галим. 1983-1986 нчы елларда нәшер ителгән инглиз, немец, француз әдәби тел тарихына бәйле хезмәтләрдә әдәби тел, әдәби норма төшенчәләрен аңлату методик һәм типологик яктан үрнәк була ала дигән фикере, безнеңчә, игътибарга лаек: «При изучении истории литературных языков совершенно необходима опора на сравнительно-типологический материал. Опираясь на фонд германских, французского, славянских языков, можно с уверенностью говорить, что тюркские литературные языки подчиняются тем же общим закономерностям сложения и развития, что и индоевропейские литературные языки. ... Настало время рассматривать процессы развития под единым углом» [Тенишев, 2006, б. 44]. Әлеге эшнең мөһимлеген аңлап, хәзерге заман лингвистика фәне югарылыгында Ә.Р. Тенишев төрки һәм, шул исәптән татар әдәби теленең үсеш үзенчәлекләрен өйрәнүгә бәйле теоретик фикерләрен бәян итә.

Сөйләмә телдән аермалы буларак, язма әдәби тел ижтимагый үсешнең билгеле бер этабында үсеш ала. Әдәби тел кануннары, нигездә, язу барлыкка килгән чор белән тыгыз бәйләнештә карала. Галимнең халык тарафыннан ижат ителеп, буыннан-буынга күчеп килгән фольклор әсәрләрен әдәби телнең бер состав өлеше - элгәресе итеп өйрәнелергә мөмкинлеге хакындагы фикере, әдәби телнең кайбер мәсьәләләрен яңача аңлатырга мөмкинлек бирә [Тенишев, 2006, б. 44].

Әдәби телнең үсеше жәмгыятьтәге вакыйгалар белән аерылгысыз мөнәсәбәттә торуына нисбәттә, Ә.Р. Тенишевның әдәби телнең үсешен ике зур чорга: милләткәчә һәм милли чорларга бүлеп өйрәнүгә бәйле нәзари фикерен билгеләп үтәргә кирәк. һәрбер чор үз эчендә тагын бүленеп, үсеш этаплары конкретлаштырылып тикшерелә. Бигрәк тә, беренче чорны өйрәнү катлаулы. Милләткәчә чорда, борынгыга таба киткән саен, язма әдәби тел һәм гомумхалык сөйләмә теле бер-берсеннән шактый нык аерыла. Әдәби телләрне өйрәнгән хезмәтләрендә тамырлары белән иң борынгы төрки язма әдәби телләргә барып тоташкан иске татар әдәби теленә зур игьтибар бирелә. Әдәби телнең тарихын өйрәнә башлаганда, ди Ә.Р.Тенишев, мәдәният үсешенә этәргеч биргән тарихи-мәдәни вакыйгалар, шәһәрләр торышы, андагы тел ситуациясе, грамоталылык дәрәжәсе, язучылар, галимнәр эшчәнлеге һәм башка әдәби тел үсешенә ярдәм иткән көчләргә игътибар итү аеруча мөһим [Тенишев, 1979, б. 80-90; 2006, б. 44]. Борынгы язма традицияләргә ия булган татар әдәби теленең катлаулы тарихын өйрәнү барышында Ә.Тенишевның нәзари фикерләре татар галимнәре хезмәтләрендә киң кулланылыш таба. Мәсәлән, соңгы елларда нәшер ителгән татар әдәби теле тарихын язган галимнәрдән И.Б. Бәширова [Бәширова, 1999], Ф.Ш. Нуриева [Нуриева, 2004], [Татар әдәби тел тарихы, 2015, 2017] хезмәтләре Ә.Р.Тенишевның фәнни-методикасына нигезләнеп башкарылган. Әлеге хезмәтләрдә конкрет бер чордагы ижтимагый hәм икътисади шартлар, тел ситуациясе, әдәби тел статусы һәм кулланылыш дәрәжәсе, традиционлык һәм яңалыгы билгеләнгән. 
Төрле тарихи-ижтимагый шартларга бәйле милләткәчә чордагы әдәби телләр бер географик төбәктән икенче төбәккә күчерелеп кулланылуын күрә алабыз, әдәби тел үзе формалашкан төбәктән еракта әдәби тел функциясен үти алган. Бу очракларда борынгы традицион тел үзенең асыл үзенчәлекләрен күпмедер дәрәжәдә саклаган хәлдә әдәби телгә региональ, жанлы сөйләм теле үзенчәлекләре үтеп кереп, әдәби телнең диалекталь нигезе үзгәреш кичерә. Бу гайре табигый хәл түгел, тарихи шартларга бәйле рәвештә милли әдәби тел оешканчыга кадәр әдәби тел вазифаларын бөтенләй чит тел дә башкарырга мөмкин. Моңа дәлил итеп, Ә.Тенишев рус һәм славян телләре тарихында иске славян теленең тоткан урынын, немец теле үсешендәге латин теленең ролен күрсәтә [Тенишев, 1994, б. 31].

Галим әдәби тел тарихын тикшергәндә, аның Yз функциясен башкара торган структурасы тулаем каралырга тиеш дип билгели hәм әдәби телнең асыл табигатен барлыкка китерә торган төп биш билге-шарты күрсәтелә: 1) эшкәртелгән-шомартылган, 2) функциональстилистик вариантлылык, 3) норма вариантлылыгы, 4) шивәләрдән өстен тору, 5) дәвамчанлыгы, традициягә ия булуы һәм тикшеренүләрдә шушы билгеләрнең һәр очракта исәпкә алынырга тиешлеге ассызыклана [Тенишев, 2006, б. 44]. Ә.Р.Тенишев шул билгеләргә нисбәттә борынгы төрки әдәби тел язма истәлекләрне, аерым алганда, Орхон-Енисей, уйгыр язмаларын, төрки халыкларның (татар, үзбәк, төрекмән, кыргыз, төрек h.б.) ядкарьләрен өйрәнгән [Тенишев, 1976 (О наддиалектном...); 1981, 1987, 1989, 2006, б.226-238; 2011, б. 186-197]. “Борынгы төрки рун язулы истәлекләрнең калыплашуы хакында" [Тенишев, 1976 (О наддиалектном...)] дип аталган мәкаләсендә Ә.Р. Тенишев телнең шул чорда барлыкка килгән үзенчәлекле төренә - койнега игътибарын юнәлтә, ягъни сөйләшү теле төрки кабиләләрдә төрлечәрәк барса да, аларның язма әдәби формасы калыплашкан, диалект теленнән өстен икәнлеген күрсәтә. Идел буенда язылган, татар әдәби теленең чишмә башы саналган “Кыйссаи Йосыф” поэмасының телен жентекле тикшергән мәкаләләрендә әдәби телнең төп үзенчәлеген хасил иткән әлеге билге-шартларның үзенчәлекләре ачыкланган. "Поэманың теле дигәч, “поэтик телнең” үзен дә яки аның стиль Үзенчәлекләреннән дә түгел, ә Үз функциясен башкара торган тулаем әдәби телнең структурасын күзалларга кирәк. Әдәби тел ул - ярымдиалект, жирле диалектларга каршы куела торган тел формасы. Алар арасында әдәби тел иң югары, иң могтәбәрле форма булып санала" [Тенишев, 1987, б. 133135; 1994, б. 31]. Ә.Р. Тенишев поэманың төп үзенчәлекләрен шушы төп биш билге яссылыгында тикшереп, "Кыйссаи Йосыф" теленең асылын, аның башка төрки телләр белән мөнәсәбәтен ачыклый.

Әдһәм Рәхим улы төрки язма әдәби телләрнең тарихын әдәби тел вариантлары кысаларында олы хезмәт язуга керешкән иде. Галим үзенең бу юнәлештәге максатын татар әдәби теле барышы мисалында башлады да. Татар теле аның өчен һәрвакыт изге туган тел булды. Татар әдәби теле тарихын өйрәнгән хезмәтләрендә Идел буенда формалашкан әдәби телнең ерак гасырларга - борынгы төрки чорларга барып тоташуын, традициондәвамчан, эшкәртелгән, төрле яссылыктагы нормаларга ия булуын билгеләп, татар халкының милли телен чагылдырган әдәби тел оешканчыга кадәр, аның берничә региональ вариантта кулланылуын аерып күрсәтте. Галимнең әлеге фикере, безнеңчә, иске татар әдәби телен тикшергәндә, аеруча игътибарга лаек. Ә.Р. Тенишев Кол Галинең “Кыйссаи Йосыф" әсәрендә ике тел ташкынының - төркихәрәзм белән угыз телләренең үрелеп баруын күрсәтә, бу катнаш телнең шактый вакыт дәвамында татар теле мохитендә дә яшәп килүен дәлили. 'Татар' дигәч, мин Идел буе татарлары элементларын күбрәк алган (киңрәк алганда, кыпчак элементларын) күз алдында тотам, ди галим. Кол Галинең бу поэмасы бердәнбер әсәр булса, ниндидер очраклык турында сүз йөртергә мөмкин булыр иде. Әмма бу алай түгел. Шундый угыз теле белән катнаш телдә XIII-XIV гасырларга караган башка әсәрләр, мәсәлән, “Кисекбаш”, “Бәдәвам", "Кыйссаи аук" һәм башкалар язылган. Ә.Р. Тенишев “Кыйссаи Йосыф"ның телен иске татар әдәби теленең жирле вариантларыннан берсе дип саный [Тенишев, 1994, б. 31; 2006, б. 282]. Ул угызлашкан әдәби тел вариантының Идел буенда бердәнбер түгеллеген, башка әдәби төре (вариантлары) булганлыгын билгели. Бу урында шуңа игътибар итәргә кирәк: Тенишев региональ вариантлылык дигәндә, милләткәчә чорда халык кулланган әдәби телнең берничә вариантта яшәве, hәр әдәби вариантның үз укучысы булуын билгели. Галим иске татар әдәби теленең милли телгә кадәр дүрт-биш, иске төрек, иске азәрбайжан, 
иске төрекмән әдәби телләре ике-өч варианттан торганлыгын искәртә. Әдһәм Тенишев иске татар әдәби теленең вариантлары нигезендә караханлы-уйгыр, төрки-хәрәзм, угыз-төрек, болгар, чагатай әдәби традицияләре һәм үз татар нигезендә формалашуын аңлата. Иске татар әдәби теленең барлык вариантларының уртаклыгының асылы аларны берләштергән татар теленең Yз нигезе булуында дигән фикерен әйтә. Рабгузинең "Кыйсасел-Әнбия", Әхмәт Ясәвинең “Хикмәт”ләренең караханлыуйгыр әдәби тел традициясенә нигезләнгән булуын күрсәтә. Төрки-хәрәзм нигезе сакланган әсәрләргә Котбның “Хөсрәү вә Ширин”, Хәрәзминең "Мәхәббәтнамә" поэмаларының телен кертә. Болгар нигезендәге әдәби вариант буларак, Идел Болгарстанының XIII-XIV гасыр эпитафик язмалары билгеләнгән, чагатай әдәби традицияләренең күпсанлы иске татар әдәби ядкарьләр нигезендә ятуын билгели [Тенишев,1983, б. 25-31; 2000, б. 27-31; 2006, б. 282]. Әлеге әдәби тел вариантларының XX гасыр башына кадәр, халык телен чагылдырган әдәби тел формалашканчыга кадәр дәвам итүен, төрле әдипләрнең үзләренә охшаган вариантта ижат итүен күрсәтә.

Ә.Р. Тенишев хезмәтләрендә әдәби телнең биш билгесенең берсе булган жанр-стиль вариантлылыгына да зур игътибар бирелә. Әдәби телне ижтимагый куллану аның функциональ стильләр системасын булдыруга китерә. Мәсәлән, дини (фәлсәфи-дидактик) әдәбият, матур әдәбиятның аерым жанрлары, фәнни әсәрләр, эш кәгазьләре, идарә, уку-укыту эшенә караган һәм шәхси язышу үзенчәлекләре. Аның шулай төрле стильләрдә кулланыла алуы әдәби телне төрле яссылыктагы күренешләр (стратлар) - диалектлар, гади сөйләм күренешләре белән тыгыз мөнәсәбәттә карауны таләп итә. Борынгы уйгыр телен әтрафлы өйрәнгән галим буларак, ул бу чорның функциональстилистик характеристикасына аерым мәкаләдә тукталып, бу чор стильләренең һәрберсенә (дини-дидактик, матур әдәбият, фәнни хезмәтләр, эш кәгазьләре, хатлар) аерым күзәтү бирә hәм үзенчәлекләрен ачыклый. Аларда тел стратлары төрлечә кулланыла алуына туктала: “Әдәби телдә милли (диалект) тел элементларының ныгып, урнашып калуы, беренче чиратта, аның стильләренә бәйле. Борынгы уйгыр телендә эш кәгазьләре стилендә һәм шәхси язышуларда милли тел (диалект) элементлары күбрәк чагылыш таба. Әмма эш кәгазьләрендә алар төрле дәрәжәдә урын ала.
Ул документның төренә бәйле: аренда шартнамәләрендә, васыятьләрдә, озак вакыт сакланырга тиешле квитанцияләрдә диалектлар, ягъни жанлы сөйләм теле элементлары аз күзәтелә, стандартлык һәм норма таләбе азрак булганнарында еш очрый” [Тенишев,1979, б. 61-78; 2006, б. 187-202]. Телнең функциональ стратификациясе әдәби телнең төрле кулланылышын күздә тота. Шуңа бәйле әдәби телнең үсеш юлларын функциональ парадигмалар нигезендә өйрәнү максатка ярашлы һәм әдәби тел тарихын өйрәнгәндә, бу юнәлеш нигез итеп алынырга тиеш, дип билгели Ә.Р. Тенишев [Тенишев, 2006, б. 187-202].

\section{Нәтижә}

Тирән белемле Әдһәм Рәхим улының фәнни эшчәнлеге күп өлкәләрне колачлый: төрки һәм алтай телләренең чагыштырма-тарихи грамматикасы, тарихи грамматика, төрки телләрнең әдәби тел тарихы, фонетика, морфология, этимология, лексикология, фольклор һәм борынгы төрки язма истәлекләр теле, хәзерге hәм тарихи диалектология, лингвокультурология. Әдһәм Рәхим улының чагыштырма-тарихи юнәлештәге дөньякүләм әһәмиятле хезмәтләре гомуми тел теориясе, бигрәк тә, телләр берлеге теориясенә зур өлеш кертә. Тел белеме фәнендә Ә.Р. Тенишев яңа фән тармагын нигезләүче галим буларак, зур бәя алды. Галимнең төрки әдәби тел тарихы буенча теоретик концепцияләренә нигезләнеп, узган гасырның 70 нче елларыннан тюркологиядә яңа юнәлеш - төрки әдәби телләр тарихы фәне барлыкка килде. Татар теле аның өчен һәрчак изге туган тел булды. Аның татар әдәби теле тарихын өйрәнгән хезмәтләрендә Идел буенда формалашкан татар әдәби телен өйрәнүнең методологик принциплары билгеләнгән.

Әдһәм Рәхим улы төрки фәненең киләчәген кайгыртып яшәде, яшь галимнәрне үстерүгә, фәнни житәкчелек итүгә аеруча зур әһәмият бирә иде. Әдһәм Рәхим улы Тенишев - 20 фән докторы hәм 30 фән кандидатының остазы. Аның аспирантлары һәм докторантлары арасында татар, башкорт, рус, төрек, казакъ, үзбәк, төрекмән, якут, уйгыр, бурят, калмык, каракалпак, карачай, балкар, азәрбайжан, чуваш, кырым татарлары халкы, европа илләре вәкилләре бар. Галимнең шәкертләре фән өлкәсендә мөһим ачышлары белән танылып, үз юнәлешләрен булдырдылар һәм дәвамчыларын үстерәләр. Шулай да Әдһәм Рәхим улы туган милләте - татар галимнәренә үз кеше булды: фәнни житәкче, рәсми бәяләүче, китапларының 
фәнни мөхәррире - гомумән, остаз ул. Гыйлем мәйданында Ә.Р. Тенишевтан фатиха алган танылган татар галимнәре Ф.Й. Йосыпов, Ф.С. Хәкимжанов, Г.Ф. Саттаров, Р.А. Йосыпов, Ф.С. Сафиуллина, Л.К. Бәйрәмова, Ф.Г. Гарипова, И.М. Низамов, Ф.Ш. Нуриева, Э.Х. Кадыйрова, Р.А. Закиров һәм башка бик күпләр үзләрен татар дөньясына армый-талмый хезмәт итүче, фәнни мәктәпләр барлыкка китергән шәхесләр итеп таныттылар. Әдһәм Рәхим улы Тенишевның фәнни мәктәбен үткән, мәрхәмәтле ярдәмен күргән галимнәрнең күңелендә остазларына карата чиксез хөрмәт, юксыну хисләре саклана. Башкортстан республикасының Фәннәр академиясендә шәрәфле академик Әдһәм Рәхим улы Тенишевның вафатыннан соң төрле елларда, төрле басмаларда дөнья күргән яки хәзергәчә нәшер ителмичә калган мәкаләләре тупланган өч томлык "Сайланма хезмәтләр” жыентыгы нәшер ителде [Избранные труды, 2006 (Книга первая); 2006 (Книга вторая); 2011]. Мәскәүдә, үзе эшләгән Россия Фәннәр академиясенең Тел белеме институтының урал-алтай бүлегендә, Казан федераль университетында һәм башка төрки дәүләт фән оешмаларында күренекле галимне хөрмәтләп, мирасын барлап, телләрне өйрәнүдә остазларына лаек фәнни казанышлары белән уртаклашу йөзеннән фәнни конференцияләр уздырыла.

\section{Йомгак өлеше}

Төрки әдәби телләр тарихын өйрәнүнең яңа этабы күренекле тюрколог-галим, безнең хөрмәтле милләттәшебез Әдһәм Рәхим улы Тенишев житәкчелегендә башлана. Әлеге этап галимнең фәнни кыйммәткә ия булган теоретик фикерләренә нигезләнеп, лингвистикадагы яңа казанышлар яктылыгында хезмәтләр язылу белән характерлана.

Әдәби тел табигате һәм вазифасы белән катлаулы күренеш тәшкил итә, аның лингвистик нигезе язма истәлекләрдә чагылыш тапкан традицияләр һәм ижтимагый тормышта барган экстралингвистик факторларда чагылыш таба. Ә.Р.Тенишевның хезмәтләрендә төрки әдәби телне өйрәнү өчен нигез булып торган түбәндәге аспектларны аерып чыгардык:

1) Төрки телләр тарихын өч юнәлештә өйрәнү: а) милли телнең тарихи грамматикасы; б) әдәби телнең тарихи грамматикасы; в) әдәби тел тарихы.

2) Дөнья әдәби телләр үсешендә типологик охшашлык булу.
3) Әдәби тел кануннары язу барлыкка килгән чор белән тыгыз бәйләнештә каралу, фольклор әсәрләрен әдәби телнең бер состав өлеше - элгәресе итеп өйрәнелә алуы.

4) Язма әсәрләрнең теле һәм гомуми тел төзелеше тармакларын берсен икенчесеннән аерып карау һәм аерым фән тармакларында тикшеру.

5) Әдәби телнең асыл табигатен барлыкка китерә торган төп биш билге-шарты: 1) эшкәртелгән-шомартылган; 2) функциональ-стилистик вариантлылык; 3) норма вариантлылыгы; 4) шивәләрдән өстен тору; 5) дәвамчанлыгы, традициягә ия булуы.

Ә.Р.Тенишев тәкъдим иткән әдәби тел, аның табигатен һәм тарихын өйрәнүгә бәйле принциплар лингвистика фәнендә тулысынча кабул ителде һәм төрки әдәби тел тарихы, хосусан, татар әдәби теле тарихы фәне галимнең теоретик фикерләренә нигезләнеп өйрәнелә. Мәшһүр галим Әдһәм Рәхим улы Тенишевның эшчәнлеге Россия фәнендә, дөнья тюркологиясендә югары бәя алды, бәрәкәтле мирасы бүген дә төрки тел гыйлеменең академик югарылыгын билгели.

\section{Әдәбият}

Бәширова И.Б. XIX гасыр ахыры - XX йөз башы татар әдәби теле: исем категорияләре һәм фигыль наклонениеләрендә әдәби норма, норма вариантлылыгы һәм функциональ - стилистик вариантлылык. Казан: КДТУ нәшр., 1999. 576 б.

Дыбо А.В. Эдхям Рахимович Тенишев // Языковые уровни и их анализ. Казань: Изд-во Татарского гос. гуманитарного института, 2001. 184 с.

Кирсанов В.И. Крупный востоковед-тюрколог // Исследование языка древнеписьменных памятников. Казань, 1980. 160 с.

Нуриева Ф.Ш. Исторические и лингвистические условия формирования тюрко-татарского литературного языка золтоордынского периода.-Казань: Казан. Гос. ун-т, 2004. 376 с.

Нуриева Ф.Ш. Татар зыялыларының затлысы // Языковые уровни и их анализ. Казань: Изд-во Татарского гос. гуманитарного института, 2001. 184 с.

Нуриева Ф.Ш., Курбатов Х.Р. Тенишев та, Еники дә, Куприн да - якын туганнар // Татарстан. 2003. №8. Б. 46-48.

Сравнительно-историческая грамматика тюркских языков. Лексика. М., 1997. 799 с.

Сравнительно-историческая грамматика тюркских языков. Лексика. Т.4. 2-е изд., М.: «Наука» 2001, $822 \mathrm{c}$.

Сравнительно-историческая грамматика тюркских языков. Морфология. М.: “Наука”, 1988. 560 с.

Сравнительно-историческая грамматика тюркских языков. Пратюркский язык-основа. Картина 
мира пратюркского этноса по данным языка. Т.6. М.: «Наука», 2006. 908 с.

Сравнительно-историческая грамматика тюркских языков. Региональные реконструкции. Т.5. М.: «Наука», 2002. 767 с.

Сравнительно-историческая

грамматика тюркских языков. Фонетика. Т.1. М., 1984. 484 с.

Татар әдәби теле тарихы (XIII гасыр - XX йөз башы). II т.: Морфология. Грамматик категорияләрнең структур-субстанциональ үзенчәлеге һәм функциональ-стилистик мөмкинлекләре: язма традицияләр, норма һәм вариантлылык. Казан: ТӘһСИ, 2017. 888 б.

Татар әдәби теле тарихы. (XIII гасыр - ХХ йөз башы) I том: Фонетика. Графика: язма традицияләр, норма һәм вариантлылык - Казан: ТӘһСИ, 2015. 696 б.

Тенишев Ә.Р. Кыйссаи Йосыф поэмасының теле // Мирас. №1, 1994. Б. 30-31.

Тенишев Э.Р. Избранные труды. Книга вторая. Уфа: Гилем, 2006. 380 с.

Тенишев Э.Р. Избранные труды. Книга первая. Уфа: Гилем, 2006. 304 с.

Тенишев Э.Р. Избранные труды. Книга третья. Уфа: ИИЯЛ УНЦ РАН, 2011. 256 с.

Тенишев Э.Р. К истории литературного языка и культуры татарского народа // Вестник АН РБ .T.5, 2000. №1. С. 27-31.

Тенишев Э.Р. Новый список Рабгузи // Историко-лингвистический анализ старописьменных памятников. Казань, 1983. С. 25-31.

Тенишев Э.Р. О киргизском литературном языке в донациональный период // Вопросы языкознания, 1989. №5. C. 32-40.

Тенишев Э.Р. О наддиалектной природе языка караханидско-уйгурских письменных памятников // Типы наддиалектных форм языка. М., 1981. С. 266277.
Тенишев Э.Р. О наддиалектном характере языка тюркских рунических памятников // Turcologica . М., 1976, С. 230-232.

Тенишев Э.Р. О наддиалектном характере языка тюркских рунических памятников // Turcologica. Л., 1976. С. 164-172.

Тенишев Э.Р. О построении истории народноразговорного и литературного языков // Тюркологические исследования. М., 1976. С. 230-232.

Тенишев Э.Р. О языке поэмы «Кысса-и Йусуф» Кул Гали // Поэт-гуманист Кул Гали. Казань: Тат.кн. изд-во, 1987. С.133-137.

Тенишев Э.Р. Принципы составления исторических грамматик и истории литературных языков // Советская тюркология. 1988. №3. С. 67-78.

Тенишев Э.Р. Родословная Тенишевых. Российская провинция XVIII-XX вв. Кн. 1. Пенза, 1996, С. 397-401.

Тенишев Э.Р. Строй саларского языка. М., 1976. $575 \mathrm{c}$.

Тенишев Э.Р. Строй сарыг-югурского языка. М., 1976. $307 \mathrm{c}$.

Тенишев Э.Р. У тюркских народов Китая. (Дневники 1956-1958 гг.). М., 1995. 240 с.

Тенишев Э.Р. Функционально-стилистическая характеристика древнеуйгурского литературного языка // Социальная и функциональная дифференциация литературных языков. М., 1977. С. 61-78.

Тенишев Э.Р. Язык произведений Давлетмухаммеда и Махтумкули Фраги // Сущность развитие и функции языка. М., 1987. С. 196-202.

Тенишев Э.Р. Языки древне- и среднетюркских памятников в функциональном аспекте // Вопросы языкознания, 1979. № 2. С. 80-90.

Хисамова Ф.М. Туган тел һәм милләт язмышы // Татарика. 2003. №1. Б. 23-35. $543 \mathrm{c}$.

\title{
ВКЛАД ИЗВЕСТНОГО УЧЕНОГО-ТЮРКОЛОГА ЭДХЯМА РАХИМОВИЧА ТЕНИШЕВА В ИЗУЧЕНИЕ ИСТОРИИ ТЮРКСКОГО И ТАТАРСКОГО ЯЗЫКОВ
}

\author{
Фануза Шакуровна Нуриева, \\ Казанский федеральный университет, \\ Россия, 420008, г. Казань, ул. Кремлевская, д. 18, \\ fanuzanurieva@yandex.ru.
}

\begin{abstract}
Статья посвящена описанию научного наследия в области истории тюркских литературных языков всемирно известного ученого, востоковеда-тюрколога Эдхяма Рахимовича Тенишева (24.04.1921 - 11.07.2004). Труды ученого анализируются с точки зрения современной истории лингвистической мысли и развития татарского языкознания. В статье дана общая характеристика научной деятельности Э. Р. Тенишева в области древнетюркских памятников, современных языков и их диалектов Центральной Азии, сравнительной грамматики тюркских языков и истории литературных языков тюркоязычных народов. Под руководством Э. Р. Тенишева в шеститомном труде по сравнительной грамматике были реконструированы
\end{abstract}


все языковые уровни, восстановлены исторические периоды развития отдельных групп тюркских языков. В статье показан вклад Э. Р. Тенишева в теорию изучения истории тюркских литературных языков, который, учитывая достижения современной типологии литературных языков, создал стройную схему последовательного развития тюркских литературных языков. Э. Р. Тенишеву принадлежит ряд статей, в которых выдвинуты методологические принципы исследования старотатарского литературного языка.

Ключевые слова: Эдхям Рахимович Тенишев, тюркология, татарский язык, тюркские языки, история литературного языка. 